\title{
The standard samples of explosives: production, certification, application
}

\author{
(C) Alina R. Krivosheeva, ${ }^{+}$Anna V. Ananeva, ${ }^{*}$ Elvira N. Tarazova, \\ Tatiana A. Eneykina, and Rose F. Gatina \\ State Research Institute of Chemical Products. Svetlaya St., 1. Kazan, 420033. Republic of Tatarstan, Russia. \\ Phone: +7 (843) 564-38-92.E-mail: aneco_ic@mail.ru
}

\begin{abstract}
*Supervising author; ${ }^{+}$Corresponding author
Keywords: standard samples, hexogen, octogen, ETN, trinitrotoluene, acetonitrile, recrystallization, acetone, methanol, a certified value, an expanded uncertainty, a homogeneity, a stability.
\end{abstract}

\section{Abstract}

The standard samples (SSs) of the compositions of hexogen (SS of Hxg), octogen (SS of Oct), ETN (SS of ETN) solutions in acetonitrile have been developed and certified for the first time. When approving each of aforesaid types of SSs, the interval of the permissible certified values has been determined as a range from $4.95 \mathrm{mg} / \mathrm{dm}^{3}$ to $5.05 \mathrm{mg} / \mathrm{dm}^{3}$ with an expanded uncertainty $(\mathrm{k}=2)$ and the bounds of a relative error $(\mathrm{P}=$ $0.95)$ of no more than $1.8 \%$. The standard sample of the composition of a trinitrotoluene solution in acetonitrile (SS of 2,4,6-TNT) with the improved metrological characteristics in comparison with the analogue (SSS 9116-2008) has been developed and certified. The interval of the permissible certified values of SS of 2,4,6-TNT was from $4.95 \mathrm{mg} / \mathrm{dm}^{3}$ to $5.05 \mathrm{mg} / \mathrm{dm}^{3}$, the expanded uncertainty $(\mathrm{k}=2)$ with the bounds of the relative error $(\mathrm{P}=0.95)$ was $1.5 \%$, which was $5 \%$ less than the analogue. The improving of the metrological characteristics of the developed SSs has been obtained by the preliminary physical cleaning of the standard explosives from the impurities, which were taken for work. The two-fold recrystallization from acetone was used for cleaning of hexogen and ETN, the one-fold recrystallization from methanol was used for trinitrotoluene, the one-fold recrystallization of explosives from acetone in the complex with dimethylformamide (DMF) was used for octogen.

\section{References}

[1] Law of Russian Federation «On the medical-epidemiological well-being of population» No. 52-FL dated the $30^{\text {th }}$ of March, 1999. (russian)

[2] GOST 12.1.005-88. «Occupational safety standards system. General medical-sanitary requirements for an air of a working zone ». Moscow: PPP Publishing house of standards. 2002. 48p. (russian)

[3] Law of Russian Federation «On ensuring the uniformity measurements» No.102-FL dated 26.06.2008. (russian)

[4] GOST ISO/IEC 17025-2009. «General requirements for a competence of testing and calibration laboratories ». Moscow: Standardinform. 2018. 27p. (russian)

[5] R.F. Government Regulation «Development of military-industrial complex» No. 425-8 dated 16.06.2016. (russian)

[6] M.Yu. Medvedevskikh, M.P. Krashenina, O.S. Shokhina. On the course of a development of a standard sample of solvent of 4,4-DDT. II-d International research conference "Standard samples in measurements and technologies". Yekaterinburg. 2015. P.89-92. (russian)

[7] E.Yu. Orlova. Octogen - a thermostable explosive. E.Yu. Orlova, N.A. Orlova, V.F. Zhilin. Moscow: Nedra. 1975. 128p. (russian)

[8] L.A. Konopelko. A quantitative description of uncertainty in analytical measurements: Guide ЕВРАХИМ СИТАК. Saint-Petersburg: the Mendeleev AlRRIM. 2002. 149p. (russian)

[9] MP 3174-2009 Recommendation. SMS. Establishment of traceability of the certified values of standard samples. Yekaterinburg: FSUE URIM. 2009. 42 p. (russian)

[10] R 50.2.058-2007 SMS. The State system for ensuring the uniformity of measurements. An evaluation of uncertainties of the attested values of standard samples. Moscow: Standardinform. 2007. 27p. (russian) 
THE STANDARD SAMPLES OF EXPLOSIVES: PRODUCTION, CERTIFICATION, APPLICATION $60-68$

[11] RIGS 93-2015 SMS. An evaluation of the metrological characteristics of standard samples Moscow: Standardinform. 2016. 27p. (russian)

[12] RIGS 53-2002 The State system for ensuring the uniformity of measurements. Standard samples. An evaluation of the metrological characteristics using the standards and model measurement means. Moscow: Standardinform. 2011. 28p. (russian) 